\title{
Characteristics and Outcomes of HCV Genotype-1-Infected Patients Treated with Peginterferon and Ribavirin Combination Therapy with Discordant HCV Responses 4 and 12 Weeks after Starting Therapy
}

\author{
Hidenori Toyoda ${ }^{a}$ Takashi Kumada $^{a}$ Noritomo Shimada ${ }^{b}$ Koichi Takaguchic \\ Tatsuya Ide $^{d}$ Michio Sata ${ }^{d}$ Hiroyuki Ginba ${ }^{e}$ Kazuhiro Matsuyama ${ }^{\text {e Namiki Izumi }}$ \\ ${ }^{a}$ Department of Gastroenterology, Ogaki Municipal Hospital, Ogaki, ${ }^{b}$ Division of Gastroenterology and Hepatology, \\ Shinmatsudo Central General Hospital, Matsudo, 'Department of Internal Medicine, Kagawa Prefectural Central Hospital, \\ Takamatsu, d Department of Digestive Disease Information and Research, Kurume University School of Medicine, \\ Kurume, ${ }^{e}$ Department of Life Cycle Management, Roche Diagnostics Japan KK, and ${ }^{f}$ Division of Gastroenterology and \\ Hepatology, Musashino Red Cross Hospital, Tokyo, Japan
}

\section{Key Words}

Chronic hepatitis C · Peginterferon · Ribavirin .

Reduction in HCV RNA levels - Early virologic response .

Treatment outcome

\begin{abstract}
Objective: Some patients with chronic hepatitis $C$ virus (HCV) infection fail to achieve complete early virologic response (EVR) despite a marked decrease in HCV RNA at 4 weeks. We investigated the characteristics and final treatment outcomes of this patient subpopulation. Methods: A total of 516 patients with HCV genotype 1 were enrolled. Background characteristics and final outcomes were compared between patients who achieved complete EVR and those who did not among patients whose HCV RNA levels decreased $3.0 \log _{10}$ or more at 4 weeks. Results: 78 of 334 patients (23.4\%) with a $\geq 3.0 \log _{10}$ reduction in HCV RNA levels at 4 weeks failed to achieve complete EVR. Female sex, higher pretreatment HCV RNA levels and lower baseline alanine aminotransferase (ALT) activity were independently as-
\end{abstract}

\section{KARGER}

E-Mail karger@karger.com

www.karger.com/int sociated with failure of complete EVR. The rate of sustained virologic response (SVR) in patients without complete EVR was $47.4 \%$, significantly lower than that in patients with complete EVR (89.7\%, p < 0.0001). Conclusions: Female patients, patients with higher pretreatment HCV RNA levels and patients with lower baseline ALT have a high likelihood of failure of complete EVR even when they had $a \geq 3 \log _{10}$ reduction of HCV RNA at 4 weeks, resulting in a significantly lower SVR rate.

(c) 2014 S. Karger AG, Basel

\section{Introduction}

The combination antiviral therapy with peginterferon (PEG-IFN) and ribavirin has markedly increased the proportion of patients who achieve a sustained virologic response (SVR), i.e. the eradication of hepatitis $\mathrm{C}$ virus (HCV), but only approximately $50 \%$ of patients infected with HCV genotype 1 achieve an SVR with this therapy. A reduction in serum HCV RNA levels 4 and 12 weeks 
after starting therapy is reportedly important to predict whether patients infected with HCV genotype 1 will ultimately achieve SVR or not with the combination therapy with PEG-IFN and ribavirin, especially when patients underwent the response-guided therapy according to the American Association for the Study of Liver Diseases (AASLD) guidelines. In particular, a reduction in $\mathrm{HCV}$ RNA levels 4 weeks after starting therapy is useful for the early prediction of treatment outcome. Several previous studies have reported that patients who achieved a rapid virologic response (RVR), undetectable serum HCV RNA levels 4 weeks after starting therapy, have a high likelihood of achieving SVR [1-4]. In addition to RVR, the degree of reduction in serum HCV RNA levels 4 weeks after starting therapy is useful; a $3.0 \log _{10}$ or more reduction in HCV RNA levels at 4 weeks indicates a high likelihood of achieving SVR even without RVR. Previous studies by Marcellin et al. [5] and our group [6] showed that a $\geq 3.0 \log _{10}$ reduction at 4 weeks is associated with a high likelihood of both achieving a complete early virologic response (EVR), i.e. undetectable serum HCV RNA 12 weeks after starting therapy, and SVR. In both studies, more than $80 \%$ of patients who had $\mathrm{a} \geq 3.0 \log _{10}$ reduction in serum HCV RNA levels at 4 weeks had complete EVR at 12 weeks. However, some patients did not achieve complete EVR despite a marked decrease in HCV RNA levels at 4 weeks.

In the present study, we attempted to clarify the characteristics and the final treatment outcome of patients who failed to achieve complete EVR at 12 weeks despite $\mathrm{a} \geq 3.0 \log _{10}$ decrease in serum HCV RNA levels at 4 weeks among Japanese patients infected with HCV genotype $1 b$ enrolled in a multi-institutional study analyzing changes in serum HCV RNA levels during the course of therapy [7].

\section{Methods}

Patients, Treatments, and Evaluation of Responses

The inclusion criteria for this multi-institutional study were: (1) infection with HCV genotype 1 without co-infection with hepatitis B virus or human immunodeficiency virus; (2) pretreatment HCV RNA levels $\geq 5.0 \log _{10} \mathrm{IU} / \mathrm{ml}$, based on a quantitative realtime PCR-based method [8, 9]; (3) standard PEG-IFN and ribavirin combination therapy according to AASLD guidelines [10] started between December 2004 and January 2010; (4) completed a treatment regimen of 48- or 72-week duration with virologic outcomes available for evaluation, and (5) 100\% medication adherence for both PEG-IFN and ribavirin during the initial 4 weeks of therapy and $80 \%$ or higher throughout the treatment period. With regard to inclusion criterion 1 , this study did not include any pa- tients infected with HCV genotype 1a because this genotype is usually not found in the Japanese general population. With regard to criterion 2, we focused on patients with pretreatment HCV RNA levels $\geq 5.0 \log _{10} \mathrm{IU} / \mathrm{ml}$ because the addition of ribavirin to PEGIFN therapy is not permitted by the Japanese National Medical Insurance System for patients with pretreatment HCV RNA levels $<5.0 \log _{10} \mathrm{IU} / \mathrm{ml}$. With regard to criterion 4 , the treatment duration was determined based on AASLD response-guided therapy guidelines. Patients in whom serum HCV RNA disappeared until 12 weeks after starting therapy (i.e. complete EVR) underwent a 48-week treatment regimen. Patients who did not achieve complete EVR but had undetectable serum HCV RNA at 24 weeks (delayed virologic response) underwent an extended 72-week treatment regimen. Patients whose treatment was discontinued due to the presence of serum HCV RNA at 24 weeks of therapy (partial responders or null responders) or due to viral breakthrough were also included in the study. As per AASLD guidelines, partial responders were defined as patients in whom serum HCV RNA was present but showed $\geq 2.0 \log _{10}$ reductions at 24 weeks of therapy, and null responders were defined as patients in whom the reduction in serum HCV RNA levels was $<2.0 \log _{10}$ at 24 weeks of therapy compared to the pretreatment levels. HCV genotype was assessed using PCR methods to amplify the core gene sequences using genotype-specific primers [11]. HCV RNA quantitation with real-time PCR was performed using the COBAS AmpliPrep/ COBAS TaqMan HCV Test version 1.0 (Roche Molecular Systems: Pleasanton, Calif., USA; lower limit of quantification, 1.6 $\log _{10} \mathrm{IU} / \mathrm{ml}$; lower limit of detection, $1.2 \log _{10} \mathrm{IU} / \mathrm{ml}$ ).

A total of 808 patients underwent combination therapy with PEG-IFN and ribavirin between December 2004 and January 2010 in one of the following five liver centers: Musashino Red Cross Hospital, Kurume University Hospital, Ogaki Municipal Hospital, Shinmatsudo Central General Hospital and Kagawa Prefectural Central Hospital. For 126 patients, the treatment regimen consisted of weekly PEG-IFN- $\alpha_{2 a}$ (Pegasys, Chugai Pharmaceutical, Tokyo, Japan) and daily ribavirin (Copegus, Chugai Pharmaceutical). The other 682 patients were treated with weekly PEG-IFN- $a_{2 b}$ (Pegintron, MSD Co., Tokyo, Japan) and daily ribavirin (Rebetol, MSD Co.). In order to avoid the influence of the PEG-IFN subtype on the association between viral dynamics and treatment outcomes, we excluded patients who had been treated with PEG-IFN$\alpha_{2 \mathrm{a}}$ and ribavirin. In 682 patients who received PEG-IFN- $\alpha_{2 b}, 516$ patients fulfilled the eligibility criteria and were included in the analysis (fig. 1).

Doses of PEG-IFN- $a_{2 b}$ and ribavirin were adjusted based on the patient's body weight. Patients were given $1.5 \mu \mathrm{g} / \mathrm{kg}$ of PEG-IFN weekly and $10 \mathrm{mg} / \mathrm{kg}$ of ribavirin daily. Dose modifications of PEG-IFN or ribavirin were based on the manufacturer's recommendations.

SVR was defined as undetectable serum HCV RNA 24 weeks after the end of therapy. A patient was considered to have relapsed when serum HCV RNA levels became detectable between the end of treatment and 24 weeks after completion of therapy, although serum HCV RNA levels were undetectable at the end of therapy. A nonresponse was defined as detectable serum HCV RNA 24 weeks after initiation of therapy (i.e. null response or partial nonresponse according to AASLD guidelines). EVR was determined 12 weeks after the start of therapy. Patients were considered to have a complete EVR if serum HCV RNA levels were undetectable 12 weeks after starting therapy. Patients were considered to have a 


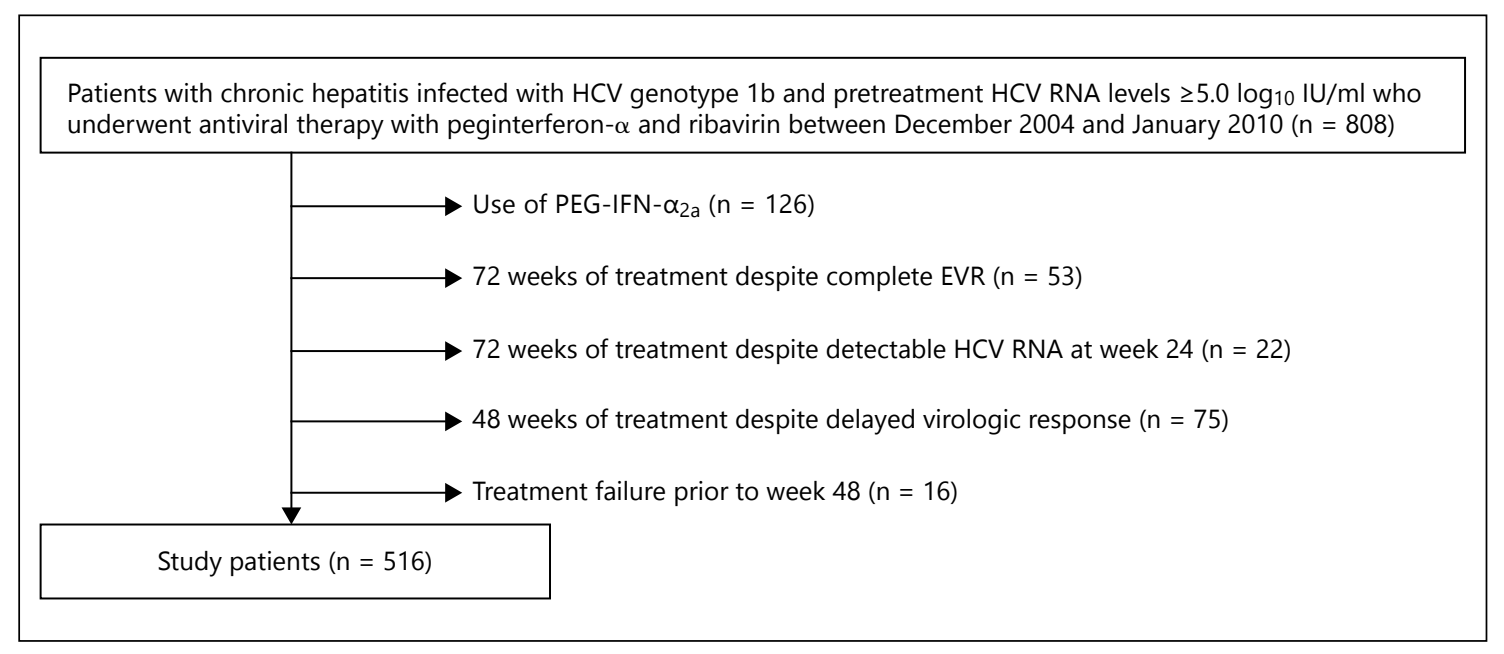

Fig. 1. Flow chart of patients enrolled in the study.

delayed virologic response if serum HCV RNA levels became undetectable after 12 weeks but until 24 weeks under treatment. RVR was determined 4 weeks after the start of therapy as undetectable serum HCV RNA.

Patients were categorized based on the RVR or the degree of reductions in serum HCV RNA levels at 4 weeks. Achievement of complete EVR in patients with RVR or a $\geq 3.0 \log _{10}$ reduction at 4 weeks was further investigated (because pretreatment serum HCV RNA levels were $\geq 5.0 \log _{10} \mathrm{IU} / \mathrm{ml}$ in all study patients, reduction in HCV RNA levels at 4 weeks of therapy in patients with RVR was $\geq 3.0 \log _{10}$ ). Factors associated with the achievement or failure for complete EVR were analyzed, and final treatment outcomes were evaluated based on complete EVR status.

The study protocol was in compliance with the Helsinki Declaration and was approved by the ethics committee of each participating institution. Prior to initiating the study, written informed consent was obtained from each patient to use his or her clinical and laboratory data and to analyze stored serum samples.

Measurements of Serum HCV RNA Levels, Amino Acid

Substitution at Residue 70 in the HCV Core, Amino Acid

Sequence of the Interferon Sensitivity-Determining Region in

HCV NS5A and Genetic Polymorphisms near the IL28B Gene

After obtaining informed consent, serum samples were obtained during the patient's regular hospital visits: just prior to beginning treatment and every 4 weeks during the treatment period and the 24-week follow-up period after treatment. Serum samples were stored at $-80^{\circ} \mathrm{C}$ until they were analyzed. HCV RNA levels were measured using a quantitative, real-time PCR-based method (COBAS AmpliPrep/COBAS TaqMan HCV Test). The reduction in HCV RNA levels 4 weeks after initiation of therapy was calculated. When calculating the decrease in serum HCV RNA levels, HCV RNA was defined as 0 when HCV RNA was undetectable or HCV RNA was detectable but too low to be unquantifiable.

Amino acid at residue 70 in the HCV core region and the amino acid sequence of the IFN sensitivity-determining region (ISDR, residues $2209-2248$ in the NS5A region) were analyzed by direct nucleotide sequencing of each region as previously described [12,
13]. The following PCR primer pairs were used for direct sequencing of the $\mathrm{HCV}$ core region:

5'-GCCATAGTGGTCTGCGGAAC-3' (outer, sense primer), 5'-GGAGCAGTCCTTCGTGACATG-3' (outer, antisense primer),

5'-GCTAGCCGAGTAGTGTT-3' (inner, sense primer) and 5'-GGAGCAGTCCTTCGTGACATG-3' (inner, antisense primer).

The following PCR primers were used for direct sequencing of the ISDR:

5'-TTCCACTACGTGACGGGCAT-3' (outer, sense primer),

$5^{\prime}$-CCCGTCCATGTGTAGGACAT-3' (outer, antisense primer),

5'-GGGTCACAGCTCCCTGTGAGCC-3' (inner, sense primer) and

5'-GAGGGTTGTAATCCGGGCGTGC-3' (inner, antisense primer).

When evaluating the ISDR, HCV was defined as wild type when there were 0 or 1 amino acid substitutions in residues 22092248 as compared with the HCV-J strain [14], and as non-wild type when there was more than 1 substitution.

Genotyping of rs8099917 polymorphisms near the IL28B gene was performed using the TaqMan SNP assay (Applied Biosystems, Carlsbad, Calif., USA) according to the manufacturer's guidelines. A predesigned and functionally tested probe was used for rs8099917 (C_11710096_10, Applied Biosystems). Genetic polymorphisms of rs8099917 reportedly correspond to rs12979860 in more than 99\% of individuals of Japanese ethnicity [15]. The TT genotype of rs8099917 corresponds to the CC genotype of rs12979860, the GG genotype of rs8099917 corresponds to the TT genotype of rs12979860, and the TG heterozygous genotype of rs8099917 corresponds to the CT genotype of rs12979860.

\section{Statistical Analyses}

Quantitative values are reported as means \pm standard deviation. Univariate and multivariate analyses using a logistic regression model were performed to identify factors that predict the failure to achieve complete EVR, including age, sex, body mass index, serum 
Table 1. Characteristics of patients based on the disappearance or the reduction in serum HCV RNA 4 weeks after starting therapy $(\mathrm{n}=$ 516)

\begin{tabular}{|c|c|c|c|c|c|}
\hline & $\begin{array}{l}\text { RVR } \\
(\mathrm{n}=116)\end{array}$ & $\begin{array}{l}\geq 3.0 \log _{10} \\
(\mathrm{n}=218)\end{array}$ & $\begin{array}{l}<3.0 \log _{10} \text { and } \\
\geq 2.0 \log _{10} \\
(\mathrm{n}=61)\end{array}$ & $\begin{array}{l}<2.0 \log _{10} \text { and } \\
\geq 1.0 \log _{10} \\
(\mathrm{n}=58)\end{array}$ & $\begin{array}{l}<1.0 \log _{10} \\
(\mathrm{n}=63)\end{array}$ \\
\hline Age, years & $56.8 \pm 11.1$ & $56.3 \pm 11.0$ & $61.7 \pm 9.0$ & $60.2 \pm 8.6$ & $60.4 \pm 7.8$ \\
\hline \multicolumn{6}{|l|}{ Sex } \\
\hline Female & $61(52.6)$ & $107(49.1)$ & $35(57.4)$ & $34(58.6)$ & $36(57.1)$ \\
\hline Male & $55(47.4)$ & $111(50.9)$ & $26(42.6)$ & $24(41.4)$ & $27(42.9)$ \\
\hline Body mass index, $\mathrm{kg} / \mathrm{m}^{2}$ & $22.9 \pm 2.8$ & $23.3 \pm 3.3$ & $22.8 \pm 3.1$ & $23.2 \pm 3.6$ & $23.5 \pm 3.6$ \\
\hline ALT, IU/l & $74.9 \pm 70.4$ & $57.0 \pm 43.6$ & $55.7 \pm 34.4$ & $60.6 \pm 34.4$ & $65.9 \pm 43.4$ \\
\hline$\gamma$-Glutamyl transpeptidase, IU/l & $52.9 \pm 79.8$ & $41.0 \pm 43.9$ & $51.8 \pm 44.8$ & $55.3 \pm 50.1$ & $46.3 \pm 41.1$ \\
\hline \multicolumn{6}{|l|}{ Liver histology-fibrosis } \\
\hline F0-1 & $44(46.3)$ & $83(58.0)$ & $22(45.8)$ & $25(54.3)$ & $24(48.0)$ \\
\hline $\mathrm{F} 2-3$ & $51(53.7)$ & $60(42.0)$ & $26(54.2)$ & $21(45.7)$ & $26(52.0)$ \\
\hline Pretreatment HCV RNA level, $\log _{10} \mathrm{IU} / \mathrm{ml}$ & $5.74 \pm 0.48$ & $6.35 \pm 0.54$ & $6.10 \pm 0.51$ & $6.09 \pm 0.55$ & $6.15 \pm 0.49$ \\
\hline \multicolumn{6}{|l|}{ Amino acid at $\mathrm{HCV}$ core 70} \\
\hline Arginine & $65(80.2)$ & $153(85.5)$ & $31(66.0)$ & $20(47.6)$ & $18(36.7)$ \\
\hline Glutamine or histidine & $16(19.8)$ & $26(14.5)$ & $16(34.0)$ & $22(52.4)$ & $31(63.3)$ \\
\hline \multicolumn{6}{|l|}{ Mutation of the ISDR } \\
\hline Non-wild type & $39(39.0)$ & $40(24.0)$ & $9(17.3)$ & $10(21.7)$ & $12(22.6)$ \\
\hline Wild type & $61(61.0)$ & $127(76.0)$ & $43(82.7)$ & $36(78.3)$ & $41(77.4)$ \\
\hline \multicolumn{6}{|l|}{ Genetic polymorphisms near the IL28B gene } \\
\hline TT & $80(97.6)$ & $173(96.6)$ & $42(84.0)$ & $19(42.2)$ & $10(18.5)$ \\
\hline TG or GG & $2(2.4)$ & $6(3.4)$ & $8(16.0)$ & $26(57.8)$ & $44(81.5)$ \\
\hline
\end{tabular}

alanine aminotransferase (ALT) activity, $\gamma$-glutamyl transpeptidase, liver fibrosis grade, pretreatment HCV RNA levels, amino acid substitution at residue 70 in the HCV core (arginine vs. glutamine or histidine), ISDR amino acid mutations (non-wild type vs. wild type) and genetic polymorphisms near the IL28B gene (rs8099917, genotype TT vs. genotype TG or GG). Data analyses were performed using JMP statistical software, version 6.0 (Macintosh version; SAS Institute, Cary, N.C., USA). All p values were two-tailed, and $\mathrm{p}<0.05$ was considered statistically significant.

\section{Results}

Patient Characteristics, HCV RNA Reduction 4 Weeks after Starting Therapy and Complete EVR

Table 1 shows the characteristics of study patients based on the disappearance or the reduction in serum HCV RNA 4 weeks after starting therapy. The prevalence of patients with glutamine or histidine of residue 70 in the HCV core region, those with wild type in the ISDR and those with TG or GG genotype of rs8099917, all of which are reportedly associated with the poorer response to the combination therapy with PEG-IFN and ribavirin, was lower in patients with a $\geq 3.0 \log _{10}$ reduction including RVR at 4 weeks in comparison to those with a $<3.0 \log _{10}$ reduction. Among the 516 patients enrolled in the study, 334 patients $(64.7 \%)$ showed a $3.0 \log _{10}$ or more reduction in HCV RNA levels 4 weeks after starting therapy. Table 2 shows the rate of complete EVR and SVR according to the reduction in serum HCV RNA levels at 4 weeks of the therapy. At 12 weeks, 256 of 334 patients (76.6\%) with a $\geq 3.0 \log _{10}$ reduction including RVR achieved complete $\mathrm{EVR}$, and the remaining 78 patients $(23.4 \%)$ failed to achieve complete EVR (fig. 2). The final treatment outcome was SVR in 272 patients (52.7\%), 90 patients (17.5\%) experienced relapse, and 128 patients $(24.8 \%)$ had a nonresponse (48 patients with partial response and 80 patients with null response). Viral breakthrough was observed in 26 patients (5.0\%). SVR was achieved in 253 of 334 patients $(75.7 \%)$ with a $\geq 3.0 \log _{10}$ reduction in serum HCV RNA levels 4 weeks after starting therapy and 19 of 182 patients $(10.4 \%)$ with a $<3.0 \log _{10}$ reduction in serum HCV RNA levels 4 weeks after starting therapy. 
Table 2. The rate of complete EVR and SVR based on the disappearance or the reduction in serum HCV RNA 4 weeks after starting therapy $(n=516)$

\begin{tabular}{|c|c|c|c|c|c|}
\hline & $\begin{array}{l}\text { RVR } \\
(n=116)\end{array}$ & $\begin{array}{l}\geq 3.0 \log _{10} \\
(\mathrm{n}=218)\end{array}$ & $\begin{array}{l}<3.0 \log _{10} \text { and } \\
\geq 2.0 \log _{10}(\mathrm{n}=61)\end{array}$ & $\begin{array}{l}<2.0 \log _{10} \text { and } \\
\geq 1.0 \log _{10}(\mathrm{n}=58)\end{array}$ & $\begin{array}{l}<1.0 \log _{10} \\
(\mathrm{n}=63)\end{array}$ \\
\hline Complete EVR & $116(100)$ & $140(64.2)$ & $9(14.8)$ & $5(8.6)$ & $2(3.2)$ \\
\hline
\end{tabular}

Percentages are given in parentheses.

Fig. 2. Distribution of patients based on reductions in serum HCV RNA levels 4 weeks after starting therapy and on EVR status 12 weeks after starting therapy. cEVR $=$ Complete EVR.

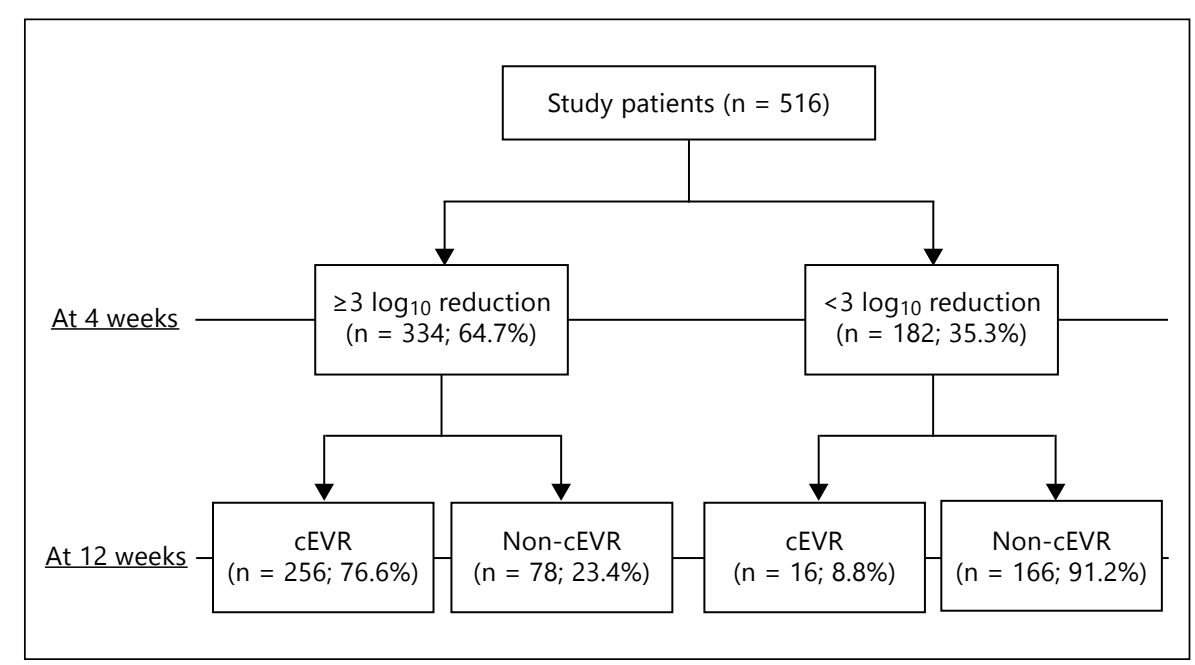

Factors Associated with the Failure to Achieve

Complete EVR in Patients with $a \geq 3.0 \log _{10}$

Reduction at 4 Weeks

Univariate and multivariate analyses were performed to identify factors associated with the failure to achieve complete EVR at 12 weeks in patients who showed a $\geq 3.0 \log _{10}$ reduction at 4 weeks (table 3 ). In univariate analysis, higher pretreatment HCV RNA levels, lower baseline ALT activity, female sex and wild-type ISDR sequence in HCV-NS5A were significantly associated with the failure to achieve complete EVR. In addition, $\gamma$-glutamyl transpeptidase had a tendency to be associated with the failure of complete EVR. Factors reportedly associated with the final outcome of combination therapy with PEG-IFN and ribavirin, such as patient age, degree of liver fibrosis, amino acid substitution at residue 70 in the HCV core region and genetic polymorphisms near the IL28B gene, were not associated with failure to achieve complete EVR. In multivariate analysis, higher pretreatment HCV RNA levels, lower baseline ALT activity and female sex were independently associated with failure to achieve complete EVR at 12 weeks.

\section{Treatment Outcomes of Patients Who Failed to}

Achieve Complete EVR despite $a \geq 3.0 \log _{10}$

Reduction at 4 Weeks

All 256 patients who achieved complete EVR underwent the 48-week standard treatment regimen according to AASLD guidelines. In 78 patients who did not achieve complete EVR, 70 (89.7\%) showed delayed virologic response and underwent the extended 72-week regimen according to AASLD guidelines, and the treatment was discontinued in the remaining 8 patients because of positive serum HCV RNA at 24 weeks. The rate of SVR was $84.4 \%$ in patients who achieved complete EVR (SVR, 216 patients; relapse, 30 patients; viral breakthrough, 10 patients). Among 256 patients who achieved complete EVR, the rate of SVR was $85.3 \%$ (99 of 116 patients) in patients with RVR and $83.6 \%$ ( 117 of 140 patients) in patients without RVR, being comparable between these two groups. In contrast, the rate of SVR was $47.4 \%$ in patients who failed to achieve complete EVR despite $\mathrm{a} \geq 3.0 \log _{10}$ reduction in serum HCV RNA levels at 4 weeks (SVR, 37 patients; relapse, 29 patients; viral breakthrough, 6 patients; partial 
Table 3. Univariate and multivariate analyses for factors associated with the failure to achieve complete EVR at week 12 in patients with a $\geq 3.0 \log _{10}$ reduction in serum HCV RNA at week 4

\begin{tabular}{|c|c|c|}
\hline & Odds ratio & $\mathrm{p}$ value \\
\hline \multicolumn{3}{|l|}{ Univariate analysis } \\
\hline Age & $2.6596(0.6453-12.025)$ & 0.1883 \\
\hline \multicolumn{3}{|c|}{ 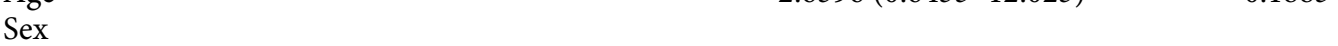 } \\
\hline Male & 1 & \\
\hline Female & $2.4138(1.4308-4.1539)$ & 0.0011 \\
\hline Body mass index & $0.7203(0.1843-2.7143)$ & 0.6316 \\
\hline ALT & $0.0095(0.0008-0.0870)$ & 0.0001 \\
\hline$\gamma$-Glutamyl transpeptidase & $0.0950(0.0078-0.8952)$ & 0.0558 \\
\hline \multicolumn{3}{|l|}{ Liver fibrosis } \\
\hline F0-1 & 1 & \\
\hline $\mathrm{F} 2-3$ & $1.0355(0.5133-2.0770)$ & 0.9216 \\
\hline Pretreatment HCV RNA level & $9.5632(3.1975-30.280)$ & 0.0001 \\
\hline \multicolumn{3}{|c|}{ Amino acid at residue 70 of the $\mathrm{HCV}$ core region } \\
\hline Arginine & 1 & \\
\hline Glutamine or histidine & $1.1571(0.5376-2.3657)$ & 0.6972 \\
\hline \multicolumn{3}{|l|}{ Mutation of the ISDR } \\
\hline Non-wild type & 1 & \\
\hline Wild type & $2.5686(1.2750-5.6452)$ & 0.0121 \\
\hline \multicolumn{3}{|c|}{ Genetic polymorphisms near the IL28B gene } \\
\hline $\mathrm{TT}$ & 1 & \\
\hline TG or GG & $0.4132(0.0219-2.3850)$ & 0.4126 \\
\hline \multicolumn{3}{|l|}{ Multivariate analysis } \\
\hline \multicolumn{3}{|l|}{ Sex } \\
\hline Male & 1 & \\
\hline Female & $4.3106(1.6011-13.094)$ & 0.0058 \\
\hline ALT & $0.0033(0.0008-0.0713)$ & 0.0253 \\
\hline$\gamma$-Glutamyl transpeptidase & $41.902(0.0031-6920.1)$ & 0.2523 \\
\hline Pretreatment HCV RNA level & $52.524(7.7420-455.48)$ & 0.0001 \\
\hline \multicolumn{3}{|l|}{ Mutation of the ISDR } \\
\hline Non-wild type & 1 & \\
\hline Wild type & $1.2181(0.4039-4.1695)$ & 0.7356 \\
\hline
\end{tabular}

Figures in parentheses indicate 95\% confidence intervals. Amino acid at residue 70 in the HCV core region, mutation of the ISDR and genetic polymorphisms near the IL28B gene (rs8099917) were not evaluated in 84, 46 and 83 patients, respectively.

response, 6 patients; fig. 3). There was no patient who achieved RVR but failed to achieve complete EVR. The rate of SVR was $10.4 \%$ in patients who did not show $\mathrm{a} \geq 3.0$ $\log _{10}$ reduction at 4 weeks (SVR, 19 patients; relapse, 31 patients; viral breakthrough, 10 patients; partial response, 42 patients; null response, 80 patients; table 2).

Among 334 patients who showed a $\geq 3.0 \log _{10}$ reduction in serum HCV RNA levels at 4 weeks including RVR, the rate of SVR was significantly lower in patients who failed to achieve complete EVR than in patients who achieved EVR ( $p<0.0001)$. In patients who did not achieve complete EVR, no differences were found in the distribution of amino acid substitutions at residue 70 of the HCV core region, ISDR amino acid sequences and rs8099917 genotype between patients who achieved SVR and those who did not (data not shown). The rate of SVR was $52.9 \%$ in 70 patients who underwent the extended 72 week regimen.

\section{Discussion}

A rapid reduction in serum HCV RNA levels usually indicates a favorable therapeutic response of infecting $\mathrm{HCV}$ and is associated with early disappearance of $\mathrm{HCV}$ RNA from the serum during therapy. Indeed, the rate of 
Fig. 3. Final treatment outcome of 334 patients with $\mathrm{a} \geq 3.0 \log _{10}$ reduction at 4 weeks of therapy based on whether complete EVR was achieved at week 12. a Patients who achieved complete EVR $(\mathrm{n}=256)$. b Patients who failed to achieve complete EVR $(\mathrm{n}=78)$.

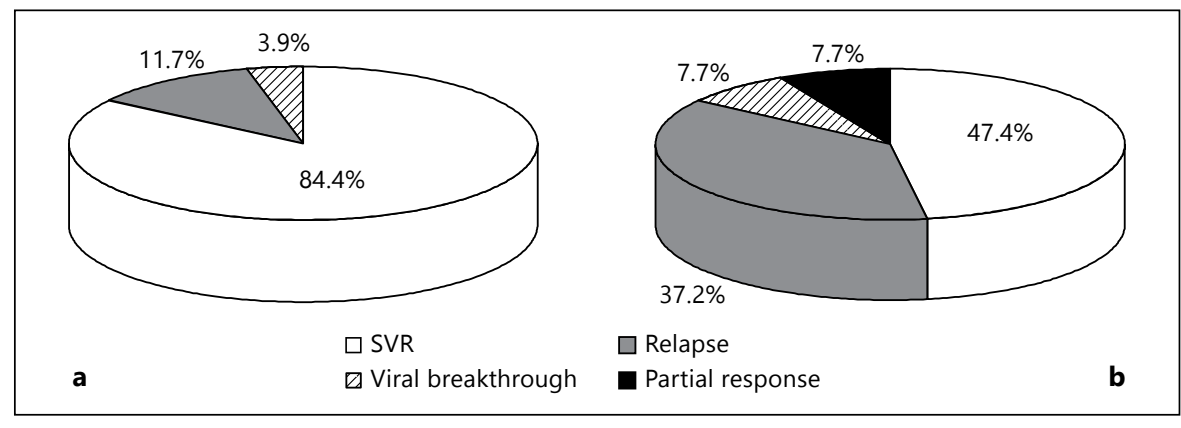

complete EVR (i.e. disappearance of HCV RNA from serum 12 weeks after starting therapy) was significantly higher in patients with a $\geq 3.0 \log _{10}$ HCV RNA reduction (76.6\%) 4 weeks after starting therapy than in patients with a $<3.0 \log _{10}$ HCV RNA reduction $(8.8 \%$, $\mathrm{p}<0.0001$; table 2; fig. 2). However, in some patients, serum HCV RNA remains detectable at 12 weeks, when EVR is determined, despite a rapid decrease in HCV RNA levels at 4 weeks.

In the present study, 78 of 334 patients (23.4\%) failed to achieve complete EVR despite a $\geq 3.0 \log _{10}$ reduction in HCV RNA levels 4 weeks after starting therapy. The percentage is comparable to that reported by Marcellin et al. [5] and in our previous study [6]. Multivariate analysis indicated that factors associated with this failure include female sex, higher pretreatment HCV RNA levels, and lower baseline ALT activity. Poorer response to PEG-IFN-based antiviral therapy in female patients had been reported with HCV genotype $1 b$ infection $[16,17]$. The delayed disappearance of HCV RNA from the serum despite a favorable response of $\mathrm{HCV}$ in its early phase may reflect this poorer response associated with female patients. In contrast, baseline host and viral factors that are reportedly strongly associated with the response to the combination therapy $[12,18-20]$ were not associated with the failure to achieve complete EVR, presumably due to decline of their impact when focusing on patients who achieved $\geq 3.0 \log _{10}$ reduction at 4 weeks. Indeed, the prevalence of patients with amino acid sequence mutations (glutamine or histidine) at residue 70 of the HCV core region and the prevalence of patients with IL28B polymorphisms (rs8099917) with GG or heterozygous TG genotypes, both of which are associated with resistance to combination therapy, were very low among the 344 patients who showed a $\geq 3.0 \log _{10}$ reduction in HCV RNA levels at 4 weeks, compared to those with a $<3.0 \log _{10}$ reduction (table 1). The resistance to PEG-IFN and ribavirin combination therapy due to

Discordant 4-Week and 12-Week HCV Status these baseline host and viral factors is associated with early reductions in $\mathrm{HCV}$ RNA levels during the first 4 weeks.

The final treatment outcome in patients who did not achieve complete EVR was poorer than in those with achieved complete EVR, despite a $\geq 3.0 \log _{10}$ reduction in HCV RNA levels at 4 weeks. The rate of SVR was below $50 \%$. Even the extended regimen for delayed virologic responders did not markedly improve the rate of SVR. Although the lack of rapid reduction in HCV RNA levels during the early treatment period (first 4 weeks) strongly indicates resistance to therapy, failure to achieve complete EVR further indicates a less favorable outcome. Therefore, viral status at week 12 retains important information to predict the treatment outcome regardless of the reduction in serum HCV RNA at week 4. Given in the emergence of oral direct-acting antivirals in the near future, discontinuation of the therapy may have to be considered for patients who failed to achieve complete EVR due to the low likelihood of achieving SVR. In addition, an extended regimen may also have to be avoided for this patient population, although the rate of SVR was rather higher (65.5\%) in patients who did not show a $\geq 3.0 \log _{10}$ reduction at 4 weeks but underwent the extended 72 -week treatment regimen because of delayed virologic response.

There are several limitations to this study. The data were based on Japanese patients infected with HCV genotype $1 \mathrm{~b}$. Therefore, these results should be confirmed in patients of other ethnicities and patients infected with $\mathrm{HCV}$ genotype 1a. In addition, the value of the reduction in HCV RNA levels at 4 and 12 weeks as predictors of SVR should also be evaluated in patients who underwent therapy with PEG-IFN- $\alpha_{2 a}$ and ribavirin. Finally, baseline host and viral factors that are associated with the response to the combination therapy were not available in some patients.

In conclusion, female patients, patients with higher pretreatment HCV RNA levels and patients with lower 
baseline ALT activity have a high likelihood of failing to achieve complete EVR at 12 weeks even when they had a $\geq 3.0 \log _{10}$ reduction in HCV RNA at 4 weeks. The rate of SVR in this subpopulation was not high despite the achievement of a $\geq 3.0 \log _{10}$ reduction at 4 weeks, even when they had a delayed virologic response and under- went an extended 72-week regimen. Further analyses on this patient subpopulation will be necessary including the efficacy of current triple combination therapy with telaprevir, PEG-IFN and ribavirin in order to decide whether they should undergo the triple therapy or await oral direct-acting antivirals becoming available.

\section{References}

1 Lee SS, Ferenci P: Optimizing outcomes in patients with hepatitis $C$ virus genotype 1 or 4 . Antiviral Res 2008;13:S9-S16.

$\checkmark 2$ Martinez-Bauer E, Crespo J, Romero-Gomez M, Moreno-Otero R, Sola R, Tesei N, Pons F, Forns X, Sanchez-Tapias JM: Development and validation of two models for early prediction of response to therapy in genotype 1 chronic hepatitis C. Hepatology 2006;43:72-80.

3 Poordad F, Reddy KR, Martin P: Rapid virologic response: a new milestone in the management of chronic hepatitis C. Clin Infect Dis 2008;46:78-84.

4 Martinot-Peignoux M, Maylin S, Moucari R, Ripault M-P, Boyer N, Cardoso A-C, Giuily M, Castelnau C, Pouteau M, Stern C, Auperin A, Bedossa P, Asselah T, Marcellin P: Virological response at 4 weeks to predict outcome of hepatitis $C$ treatment with pegylated interferon and ribavirin. Antivir Ther 2009;14 501-511.

5 Marcellin P, Reau N, Ferenci P, Hadziyannis S, Messinger D, Tatsch F, Jensen D: Refined prediction of week 12 response and SVR based on week 4 response in HCV genotype 1 patients treated with peginterferon alfa-2a $(40 \mathrm{kD})$ and ribavirin. J Hepatol 2012;56:1276-1282.

-6 Toyoda H, Kumada T, Kiriyama S, Tanikawa M, Hisanaga Y, Kanamori A, Tada T, Arakawa T, Fujimori M, Niinomi T, Ando N, Yasuda S, Sakai K, Kimura J: High ability to predict the treatment outcome of peginterferon and ribavirin combination therapy based on the reduction in HCV RNA levels at 4 weeks after starting therapy and amino acid substitutions in hepatitis $C$ virus in patients infected with HCV genotype 1b. J Gastroenterol 2011;46: 501-509.

7 Toyoda H, Kumada T, Shimada N, Takaguchi K, Ide T, Sata M, Ginba H, Matsuyama K, Izumi N: Significance of a reduction in $\mathrm{HCV}$ RNA levels at 4 and 12 weeks in patients infected with HCV genotype $1 \mathrm{~b}$ for the prediction of the outcome of combination therapy with peginterferon and ribavirin. BMC Infect Dis 2012;12:324.
8 Colucci G, Ferguson J, Harkleroad C, Lee S, Romo D, Soviero S, Thompson J, Velez M, Wang A, Miyahara Y, Young S, Sarrazin C: Improved COBAS TaqMan hepatitis $\mathrm{C}$ virus test (version 2.0) for use with the High Pure system: enhanced genotype inclusivity and performance characteristics in a multisite study. J Clin Microbiol 2007;45:3595-3600.

-9 Pittaluga F, Allice T, Abate ML, Ciancio A, Cerutti F, Varetto S, Colucci G, Smedile A, Ghisetti V: Clinical evaluation of the COBAS Ampliprep/COBAS TaqMan for HCV RNA quantitation in comparison with the branched-DNA assay. J Med Virol 2008;80: 254-260.

10 Ghany MG, Strader DB, Thomas DL, Seeff LB: Diagnosis, management, and treatment of hepatitis C: an update. Hepatology 2009;49: 1335-1374.

-11 Ohno T, Mizokami M, Wu RR, Saleh MG Ohba K, Orito E, Mukaide M, Williams R, Lau JYN: New hepatitis C virus (HCV) genotyping system that allows for identification of HCV genotypes $1 \mathrm{a}, 1 \mathrm{~b}, 2 \mathrm{a}, 2 \mathrm{~b}, 3 \mathrm{a}, 3 \mathrm{~b}, 4,5 \mathrm{a}$, and 6a. J Clin Microbiol 1997;35:201-207.

-12 Akuta N, Suzuki F, Kawamura Y, Yatsuji H, Sezaki H, Suzuki Y, Hosaka T, Kobayashi M, Kobayashi M, Arase Y, Ikeda K, Miyakawa Y, Kumada H: Prediction of response to pegylated interferon and ribavirin in hepatitis $\mathrm{C}$ by polymorphisms in the viral core protein and very early dynamics of viremia. Intervirology 2007;50:361-368.

13 Enomoto N, Sakuma I, Asahina Y, Kurosaki M, Murakami T, Yamamoto C, Ogura Y, Izumi N, Marumo F, Sato C: Mutations in the nonstructural protein $5 \mathrm{~A}$ gene and response to interferon in patients with chronic hepatitis $\mathrm{C}$ virus $1 \mathrm{~b}$ infection. N Engl J Med 1996; 334:77-81.

14 Kato N, Hijikata M, Ootsuyama Y, Nakagawa M, Ohkoshi S, Sugimura T, Shimotohno K: Molecular cloning of the human hepatitis $\mathrm{C}$ virus genome from Japanese patients with non-A, non-B hepatitis. Proc Natl Acad Sci USA 1990;87:9524-9528.
15 Tanaka Y, Nishida N, Sugiyama M, Tokunaga $\mathrm{K}$, Mizokami M: $\lambda$-Interferons and the single nucleotide polymorphisms: a milestone to tailor-made therapy for chronic hepatitis C. Hepatol Res 2010;40:449-460.

16 Sezaki H, Suzuki F, Kawamura Y, Yatsuji H, Hosaka T, Akuta N, Kobayashi M, Suzuki Y, Saitoh S, Arase Y, Ikeda K, Miyakawa Y, Kumada $\mathrm{H}$ : Poor response to pegylated interferon and ribavirin in older women infected with hepatitis $\mathrm{C}$ virus of genotype $1 \mathrm{~b}$ in high viral loads. Dig Dis Sci 2009;54:1317-1324.

17 Watanabe S, Enomoto N, Koike K, Izumi N, Takikawa H, Hashimoto E, Moriyasu F, Kumada H, Imawari M; PERFECT Study Group: Prolonged treatment with pegylated interferon $\alpha 2 b$ plus ribavirin improves sustained virologic response in chronic hepatitis $\mathrm{C}$ genotype 1 patients with late response in a clinical real-life setting in Japan. Hepatol Res 2010;40: 135-144.

18 Ge D, Fellay J, Thompson AJ, Simon JS, Shianna KV, Urban TJ, Heinzen EL, Qiu P, Bertelsen AH, Muir AJ, Sulkowski M, McHutchison JG, Goldstein DB: Genetic variation in IL28B predicts hepatitis C treatment-induced viral clearance. Nature 2009;461:399-401.

19 Suppiah V, Moldovan M, Ahlenstiel G, Berg T, Weltman M, Abate ML, Bassendine M, Spengler U, Dore GJ, Powell E, Riordan S, Sheridan D, Smedile A, Fragomeli V, Müller T, Bahlo M, Stewart GJ, Booth DR, George J: $I L 28 B$ is associated with response to chronic hepatitis $\mathrm{C}$ interferon-alpha and ribavirin therapy. Nat Genet 2009;41:1100-1104.

20 Tanaka Y, Nishida N, Sugiyama M, Kurosaki M, Matsuura K, Sakamoto N, Nakagawa M, Korenaga M, Hino K, Hige S, Ito Y, Mita E, Tanaka E, Mochida S, Murawaki Y, Honda M, Sakai A, Hiasa Y, Nishiguchi S, Koike A, Sakaida I, Imamura M, Ito K, Yano K, Masaki N, Sugauchi F, Izumi N, Tokunaga K, Mizokami M: Genome-wide association of IL28B with response to pegylated interferon-alpha and ribavirin therapy for chronic hepatitis C. Nat Genet 2009;41:1105-1109. 